\title{
Effects of Biochar on Soil Quality and Heavy Metal Availability in a Military Shooting Range Soil in Korea
}

\author{
Sung-Eun Lee, Mahtab Ahmad ${ }^{1}$, Adel A. R. A. Usman ${ }^{1}$, Yasser M. Awad ${ }^{1}$, Sun-Hong Min ${ }^{2}$, \\ Jae E Yang ${ }^{1}$, Sang Soo Lee ${ }^{1 * * *}$, and Yong Sik $\mathrm{OK}^{1 *}$ \\ Nanotox Tech, Inc., Ansan 425-702, Korea \\ ${ }^{1}$ Department of Biological Environment, Kangwon National University, Chuncheon 200-701, Korea \\ ${ }^{2}$ Department of Urban \& Environmental Disaster Prevention, Graduate School of Disaster Prevention, \\ Kangwon National University, Samcheok 245-711, Korea
}

\begin{abstract}
Heavy metal remediation in shooting range soil is a challenge over the wordd. The excessive $\mathrm{Pb}$ accumulation in the soil can deteriorate soil quality and fertility. The objectives of this research were to evaluate the efficiency of biochar (BC) in improving the physicochemical and biological properties of the soil and to evaluate its effect on $\mathrm{Pb}$ availability in a military shooting range soil. Sandy loam soil was collected from shooting range of Gyeonggi Province, South Korea and was incubated for 30 days with different application rates $\left(0-30 \% \mathrm{w} \mathrm{w}^{-1}\right)$ of $\mathrm{BC}$. The results showed that the addition of $\mathrm{BC}$ increased aggregate stability, nitrogen $(\mathrm{N})$ and phosphorus (P) contents, and enzyme activities in soil. Sequential extraction showed that residual and organic bound fractions in the soil amended with $\mathrm{BC}$ increased by 33.1 and $16.7 \%$, respectively, and the exchangeable fraction decreased by $93.7 \%$ in the soil amended with $\mathrm{BC}$, compared to the unamended soil. We concluded that the application of $\mathrm{BC}$ could not only improve physicochemical and biological soil qualities but also stabilize $\mathrm{Pb}$ in a shooting range soil.
\end{abstract}

Key words: Shooting range, Heavy metals, Biochar, Soil quality, Lead

\section{Introduction}

Shooting ranges are essential constructions around the world for weapons training and shooting activities. However, shooting activities produce the soil contaminated with heavy metals such as $\mathrm{Pb}$ from the used bullets (Dermatas et al., 2006). Nowadays, a huge amount of $\mathrm{Pb}$ is being deposited in the shooting range soil worldwide at an annual deposition rate of 200 to 60,000 tons (Craig, 1999; Mellor and McCartney, 1994). Shooting ranges are commonly considered as the second largest source of soil $\mathrm{Pb}$ after development of the battery industry (Cao et al., 2008). The contamination of shooting range soil with $\mathrm{Pb}$ is well documented (Cao et al., 2008; Dermatas et al., 2006; Grubb et al., 2009; Hashimoto et al., 2009a). Most of the

\footnotetext{
Received : January 20. 2011 Accepted : February 17. 2011

*Corresponding author : Phone: +82-33-250-6443

E-mail: soilok@kangwon.ac.kr

**Corresponding author : Phone: +82-33-250-7214

Email: sslee97@kangwon.ac.kr
}

studies indicated that $\mathrm{Pb}$ levels in the shooting range soils exceed 1\% (Chen and Daroub, 2002; Hashimoto et al., 2010) resulting in degrading soil quality, decreasing soil microbial activities and threating to living organisms (Belyaeva et al., 2005; Lee et al., 2002).

The remediation of shooting range soil has received great interest in the past due to its adverse effects. There are several remediation technologies for remediating heavy metal contaminated soils, such as excavation and landfill, thermal treatment, washing, electro-reclamation, and solidification/stabilization (Aboulroos et al., 2006; Shi and Spence, 2004; Singh and Pant, 2006). However, because of the high cost and low efficiency, these conventional methods are not effective (Aboulroos et al., 2006). The end use of the contaminated soil after remediation is an important factor, which controls the selection of remediation technology (Mulligan et al., 2001). Several soil amendments such as $\mathrm{P}$ containing materials and liming materials have been used to remediate the shooting range soil by convertting highly mobile and available forms of $\mathrm{Pb}$ into less mobile and available forms (Cao et al., 2008; Hashimoto 
et al., 2009a; Li et al., 2009; Moon et al., 2010). However, phosphate-induced immobilization of $\mathrm{Pb}$ requires a high amount of available $\mathrm{P}$ to stabilize $\mathrm{Pb}$ that may result in the leaching of $\mathrm{P}$ into ground water and surrounding environment (Dermatas et al., 2008). On the other hand, rise in the soil $\mathrm{pH}(>8)$ induced by the lime-based materials for $\mathrm{Pb}$ stabilization is not favorable for soil biota.

Biochar (BC) is a charcoal produced from the pyrolysis of biomass at relatively low temperatures $\left(<700^{\circ} \mathrm{C}\right)$ (Lehmann and Joseph, 2009). BC has received great interest during the last few years, due to its beneficial role to mitigate $\mathrm{CO}_{2}$ emission and to improve soil quality (Major, 2010; Novak et al., 2009). Several studies have shown that $\mathrm{BC}$ can improve physicochemical and biological soil properties (Free et al., 2010; Novak et al., 2009; Yeboah et al., 2009). However, in our knowledge, $B C$ has not been widely used so far as a soil amendment for shooting range soils. Additionally, only limited studies have reported on the effect of $\mathrm{BC}$ for heavy metal availablity and stabilization in soil.

Recently, Cao et al. (2009) indicated that high content of $\mathrm{P}$ in the $\mathrm{BC}$ is mainly responsible for $\mathrm{Pb}$ stabilization in the aqueous solution due to the formation of stable phosphate minerals. Uchimiya et al. (2010) suggested several possible mechanisms for the stabilization of heavy metals in soil and water by using BC, such as cation exchange, coordination by $\pi$ electrons of carbon (C) and precipitation. However, most of these studies applied $\mathrm{BC}$ to immobilize heavy metals in aqueous solutions or soils but only for a short incubation period $(24 \mathrm{~h})$. Therefore, the effectiveness of $\mathrm{BC}$ for the stabilization of heavy metals in soils has not been well explored.

In South Korea, there are more than 690 shooting ranges where 267 tons year ${ }^{-1}$ of $\mathrm{Pb}$ deposited annually (Ministry of Environment (MOE), 2010). However, little information is available for the soil and water contamination of these sites. Therefore, the objectives of this study are (i) to evaluate the efficiency of $\mathrm{BC}$ in improving soil quality related to physicochemical and biological properties, and (ii) to determine its performance on availability and stabilization of heavy metals in a military shooting range soil.

\section{Material and methods}

Soil collection $\quad \mathrm{A} \mathrm{Pb}$ contaminated surface soil was collected from the impact berm (200 m from the firing station) of a military shooting range in Gyeonggi Province, South Korea. Soil samples were air-dried and had all $\mathrm{Pb}$-contained bullets removed passed through a 2-mm sieve, after which subjected to further analysis and the incubation experiment.

Biochar amendment Biochar material (BC250) or BC for short was obtained from University of Bayreuth, Germany, and comprised of 250-kg charcoal mixed with one ton of compost material (50\% sewage sludge $+25 \%$ freshly chopped lop, grass and leaves $+25 \%$ of soil and coarse wood branches). Organic matter (OM) in BC was determined by loss on ignition method (Yerokun et al., 2007). The $B C$ was ground to pass through a $0.5-\mathrm{mm}$ sieve and used for the incubation experiment.

Incubation experiment A soil incubation experiment was conducted using $\mathrm{BC}$ at different application rates 0,1 , 3, 5, 10, 20 and 30\% (weight basis of soil). Specifically, $100 \mathrm{~g}$ of shooting range soil was thoroughly mixed with $\mathrm{BC}$ in a high-density polyethylene (HDPE) container. The soil was hydrated to saturation in order to promote the reaction between metal ions and $\mathrm{BC}$, and the hydrated conditions were maintained by periodically adjusting the weights of containers. Then, soil was incubated for $30 \mathrm{~d}$ at room temperature without direct sunlight exposure.

Soil analysis The particle size distribution was determined using a hydrometer method as described by Gee and Or (2002). The soil aggregate stability was determined using a wet sieving apparatus (Eijkelkamp, Netherlands). To ensure soil particle distribution, $4 \mathrm{~g}$ of 1- to 2-mm air-dried soil aggregate was pre-moistened with distilled water and then was sieved through $0.25 \mathrm{~mm}$ into $80 \mathrm{~mL}$ of distilled water for $3 \mathrm{~min} \pm 5 \mathrm{~s}$. The water was then evaporated in a dry oven at $110^{\circ} \mathrm{C}$ to get unstable aggregates. Meanwhile, the remaining soil aggregate was sieved into $80 \mathrm{~mL}$ of dispersing solution $\left(2 \mathrm{~g} \mathrm{~L}^{-1}\right.$ sodium hexametaphosphate for the soil with $\mathrm{pH}>7$ or $2 \mathrm{~g} \mathrm{~L}^{-1}$ sodium hydroxide for the soil with $\mathrm{pH}<7$ ) until only sand particles left on the sieve. Finally, the sample was evaporated and the stable aggregate fraction was calculated.

The soil $\mathrm{pH}$ and $\mathrm{EC}$ was determined at room temperature by following the 1:5 soil/water extraction methods (NIAST, 2000). Total organic carbon (TOC) content was determined using a Walkley-Black procedure (Nelson and Sommers, 1996), and total C (TC) and total nitrogen (TN) were measured using an elemental analyzer (Flash EA 1112, 
Thermo-electron Corporation, USA). Dissolved organic carbon (DOC) was measured by a TOC analyzer (TOC 5000A, Shimadzu, Japan). Soil samples for ammonium and nitrate determination were extracted with $2 \mathrm{M} \mathrm{KCl}$. Ammonium- $\mathrm{N}$ was measured by an indophenol method as described by Selmer-Olsen (Selmer-Olsen, 1971) and nitrate-N was measured by a spectrophotometer method according to Doane and Horwath (2003), while chlorostannous acid method was adopted to determine available $\mathrm{P}$ (Kuo et al., 1996). Total metal contents were determined following the digestion (Mars-X, HP-500 plus, CEM Corporation) according to the USEPA method 3051A (Chirenje et al., 2003). Toxicity characteristics leaching procedure (TCLP) and water extractions were applied to evaluate the leachabillity of $\mathrm{Pb}$ and $\mathrm{Cu}$ from the amended shooting range soil with $\mathrm{BC}$. The TCLP procedure was performed following the USEPA method 1311 (USEPA, 1992). A sequential extraction procedure was adopted to classify and quantify the $\mathrm{Pb}$ fraction of the soil amended with $\mathrm{BC}$ according to the procedure of Tessier et al. (1979). The sequential extraction consists of five $\mathrm{Pb}$ fractions (exchangeable [using $1 \mathrm{M}$ magnesium chloride], carbonate-associated [using $1 \mathrm{M}$ sodium acetate], $\mathrm{Fe} / \mathrm{Mn}$ associated [using 0.04 M hydroxyl amine-hydrochloride in $25 \%$ acetic acid], organically associated [using $30 \%$ hydrogen peroxide and $0.02 \mathrm{M}$ nitric acid], and residual [using aqua regia]). Water-soluble $\mathrm{Cu}$ and $\mathrm{DOC}$ were determined using deionized water with a 1:10 soil-solution ratio. The supernatant solution of each extraction was filtered through a 42 Whatman filter paper. Soil $\mathrm{Pb}$ and $\mathrm{Cu}$ in the digests and TCLP extractions, water-soluble $\mathrm{Cu}$ and sequential extraction $\mathrm{Pb}$ were measured by atomic absorption spectroscopy (AAS 700, Perkin Elmer, USA).

For soil biological analysis, colony forming units (CFUs) counts were adopted to evaluate the effects of $\mathrm{BC}$ amendments on total microbial population (bacteria and fungi) following the description of Taok (2007). Briefly, microorganisms were extracted from soil matrix by making a 100 -fold serial dilution using sterile physiological water. The mixture was then shaken vigorously on a vortex for 5 min. Different dilutions were prepared from the supernatant using inoculate petri dishes. Total bacterial counts were performed using nutrient agar medium (Difco). Furthermore, total fungal counts were performed on potato dextrose agar medium (Difco) supplemented by Rose Bengal (1 mg $\mathrm{L}^{-1}$ ) to inhibit the bacterial growth. Bacterial colonies were counted after $72 \mathrm{~h}$ incubation at $30^{\circ} \mathrm{C}$ and fungi colonies were counted after seven days incubation at $27^{\circ} \mathrm{C}$. The activity of five enzymes in the shooting range soil amended with $\mathrm{BC}$ was analyzed colorimetrically by a spectrophotometer (Shimadzu-UV 1800). Dehydrogenase activity was measured following the method of Tabatabai (1994). Six grams from a mixture of $20 \mathrm{~g}$ of air-dried soil $\left(<2 \mathrm{~mm}\right.$ ) and $0.2 \mathrm{~g}$ of $\mathrm{CaCO}_{3}$ were exposed to $1 \mathrm{~mL}$ of $3 \%$ aqueous solution of TTC (2, 3, 5-triphenyltetrazolium chloride) for $24 \mathrm{~h}$ in the dark at $37^{\circ} \mathrm{C}$. The soil was washed and transferred with sufficient amount of methanol, and the concentration of triphenyleformazan in the extracted solution was determined by measuring the intensity of the red color at $485 \mathrm{~nm}$. Urease activity was determined (Tabatabai, 1994). Five grams of $<2 \mathrm{~mm}$ oven-dried soil was exposed to $5 \mathrm{~mL}$ of urea solution ( $10 \mathrm{mg}$ of urea) for $5 \mathrm{~h}$ at $37^{\circ} \mathrm{C}$ and admixed with $50 \mathrm{~mL}$ of $2 \mathrm{M} \mathrm{KCl}$ solution by shaking for $1 \mathrm{~h}$. The concentration of $\mathrm{NH}_{4}{ }^{+}$in the extracted solution was determined by measuring the optical density of the color at $690 \mathrm{~nm}$. Acid and alkaline phosphatases were also measured (Tabatabai, 1994). One gram of soil was exposed to $0.2 \mathrm{~mL}$ of toluene, $4 \mathrm{~mL}$ of buffer solution (adjusting the $\mathrm{pH} 6.5$ for acid phosphatase and $\mathrm{pH} 11$ for alkaline phosphatase), and $1 \mathrm{~mL}$ of PNP (p-nitrophenyl phosphate) for $1 \mathrm{~h}$ at $37^{\circ} \mathrm{C}$. The soil was admixed with 5 $\mathrm{mL}$ of solution consisted of $1 \mathrm{~mL}$ of $0.5 \mathrm{~mol} \mathrm{~L}^{-1} \mathrm{CaCl}_{2}$ and $4 \mathrm{~mL}$ of $0.5 \mathrm{~mol} \mathrm{~L}^{-1} \mathrm{NaOH}$, and the concentration of p-nitrophenol in the extracted solution was determined at a wave length of $410 \mathrm{~nm}$.

Statistics Results were statistically analyzed using the SAS package (ver. 9.1). Means of three replicates for all physicochemical and biological findings were subjected to one way ANOVA. The Tukey's honestly significant difference (HSD) studentised range test was applied for significant differences among means $(\mathrm{p}<0.05)$. Pearson's correlation coefficient was also calculated among various parameters.

\section{Results}

Soil and biochar characterization Table 1 shows selected physicochemical characteristics of the studied shooting range soil and $\mathrm{BC}$. The soil had a sandy loam texture. Soil $\mathrm{pH}$ was slightly acidic (6.66) with $0.025 \mathrm{dS}$ $\mathrm{m}^{-1} \mathrm{EC}$ value. Soil was relatively low in $\mathrm{OM}(1.04 \%)$, and available $\mathrm{N}\left(15.01 \mathrm{mg} \mathrm{kg}^{-1}\right)$ and $\mathrm{P}\left(8.65 \mathrm{mg} \mathrm{kg}^{-1}\right)$ contents. Total $\mathrm{Pb}$ and $\mathrm{Cu}$ concentrations in the soil were 4,626 and $225 \mathrm{mg} \mathrm{kg}^{-1}$, respectively. These results indicated that the shooting range soils were severely contaminated by $\mathrm{Pb}$ 
Table 1. Characteristics of shooting range soil and biochar.

\begin{tabular}{cccc}
\hline \hline Parameters & Unit & Soil & Biochar \\
\hline Sand & $\%$ & 56.6 & - \\
Silt & $\%$ & 29.4 & - \\
Clay & $\%$ & 14 & $6.29 \pm 0.02$ \\
pH & - & $6.66 \pm 0.04$ & $93.04 \pm 0.97$ \\
$\mathrm{OM}^{\dagger}$ & $\%$ & $1.04 \pm 0.05$ & $67.00 \pm 1.91$ \\
Total C & $\%$ & $0.58 \pm 0.02$ & $2.73 \pm 0.10$ \\
Total N & $\%$ & $0.045 \pm 0.0$ & $300.14 \pm 6.61$ \\
Available N & $\mathrm{mg} \mathrm{kg}^{-1}$ & $15.01 \pm 0.82$ & $290.93 \pm 3.64$ \\
Available P & $\mathrm{mg} \mathrm{kg}^{-1}$ & $8.65 \pm 1.63$ & $\mathrm{BDL}^{\ddagger}$ \\
Total Pb & $\mathrm{mg} \mathrm{kg}^{-1}$ & $4,626 \pm 268$ & $15.23 \pm 4.01$ \\
Total Cu & $\mathrm{mg} \mathrm{kg}^{-1}$ & $225 \pm 82$ & \\
\hline
\end{tabular}

${ }^{\dagger}$ Organic matter.

${ }^{\ddagger}$ Below detection level.

Table 2. Changes in soil physicochemical properties as affected by $\mathrm{BC}$ application. Means with the same letter within a column are not significantly different at $\mathbf{p}<\mathbf{0 . 0 5}$.

\begin{tabular}{|c|c|c|c|c|c|c|c|}
\hline Rates & $\begin{array}{c}\text { Aggregate } \\
\text { stability }\end{array}$ & $\mathrm{pH}$ & $\mathrm{OM}^{\dagger}$ & Total C & Total N & $\begin{array}{c}\text { Available } \\
\mathrm{N}\end{array}$ & $\begin{array}{c}\text { Available } \\
\text { P }\end{array}$ \\
\hline$\%$ & $\%$ & & $\%$ & $\%$ & $\%$ & $\mathrm{mg} \mathrm{kg}^{-1}$ & $\mathrm{mg} \mathrm{kg}^{-1}$ \\
\hline 0 & $8.76 f$ & $6.10 \mathrm{e}$ & $1.04 \mathrm{ef}$ & $0.65 f$ & $0.03 \mathrm{f}$ & $15.00 \mathrm{e}$ & $7.51 \mathrm{c}$ \\
\hline 1 & $12.55 \mathrm{e}$ & $6.52 \mathrm{~d}$ & $0.92 \mathrm{f}$ & $1.11 \mathrm{ef}$ & $0.04 \mathrm{ef}$ & $31.09 \mathrm{e}$ & $8.42 \mathrm{c}$ \\
\hline 3 & $15.00 \mathrm{ed}$ & $7.21 \mathrm{c}$ & $1.51 \mathrm{ed}$ & $2.05 \mathrm{ed}$ & $0.08 \mathrm{ed}$ & $66.48 \mathrm{~d}$ & $13.51 \mathrm{c}$ \\
\hline 5 & $16.66 \mathrm{~d}$ & $7.68 \mathrm{~b}$ & $1.76 \mathrm{~d}$ & $2.93 d$ & $0.15 d$ & $119.28 \mathrm{c}$ & $17.78 \mathrm{c}$ \\
\hline 10 & $20.07 \mathrm{c}$ & $7.78 \mathrm{~b}$ & $2.77 \mathrm{c}$ & $5.15 \mathrm{c}$ & $0.26 \mathrm{c}$ & $140.32 \mathrm{cb}$ & $21.21 \mathrm{c}$ \\
\hline 20 & $24.75 b$ & $7.94 b$ & $4.12 b$ & $10.00 \mathrm{~b}$ & $0.44 \mathrm{~b}$ & $150.14 b$ & $40.54 b$ \\
\hline 30 & $29.41 \mathrm{a}$ & $8.22 \mathrm{a}$ & $5.00 \mathrm{a}$ & $13.43 \mathrm{a}$ & $0.59 \mathrm{a}$ & $180.20 \mathrm{a}$ & $60.35 \mathrm{a}$ \\
\hline
\end{tabular}

${ }^{\dagger}$ Organic matter.

due to the excessive activity of shooting practices. According to the Ministry of Environment, South Korea (MOE, 2010), the concentration of $\mathrm{Pb}$ in shooting ranges is 6.61-folds greater than warning limits of the military shooting range areas $\left(700 \mathrm{mg} \mathrm{kg}^{-1}\right)$ and greatly exceeds the USEPA screening level of $400 \mathrm{mg} \mathrm{kg}^{-1}$ (USEPA, 1996).

Biochar was slightly acidic with a $\mathrm{pH}$ value of 6.29, and $\mathrm{EC}$ value of $0.004 \mathrm{dS} \mathrm{m}^{-1}$. The slightly acidic $\mathrm{pH}$ of $\mathrm{BC}$ may be induced from the compost material, especially sewage sludge (Singh and Agrawal, 2007). Verheijen et al. (2010) indicated that the $\mathrm{pH}$ values of $\mathrm{BC}$ produced from a wide variety of feedstocks with a mean of $\mathrm{pH} 8.1$ in a total range of $\mathrm{pH}$ 6.2-9.6. The values of TC and TN of $\mathrm{BC}$ were 67 and $2.73 \%$ by weight, which are in the range of reported values (17.2-90.5\% for $\mathrm{C}$ and 0.17 $7.82 \%$ for $\mathrm{N}$ ) in various studies (Verheijen et al., 2010). Moreover, $\mathrm{BC}$ had high concentrations of the available
$\mathrm{N}$ (300.14 $\mathrm{mg} \mathrm{kg}^{-1}$ ), available P (290.93 $\mathrm{mg} \mathrm{kg}^{-1}$ ) and $\mathrm{OM}(93.04 \%)$. The available $\mathrm{P}$ content of $\mathrm{BC}$ was similar to other reported values $\left(290.93 \mathrm{mg} \mathrm{kg}^{-1}\right)$ for BC materials (Novak et al., 2009).

Aggregate stability The aggregate stability of unamended and amended soil samples is shown in Table 2. Application of BC significantly increased the soil aggregate stability with higher rates. Maximum aggregate stability, which was 3.36-fold greater than the unamended soil, was observed in the soil amended with $30 \%$ BC. The correlation study showed that soil aggregate stability was highly correlated with soil OM $(\mathrm{p}<0.001)$ (Table 3$)$.

Heavy metals availability Shooting range soil amended with BC caused a pronounced reduction of the TCLP leachable $\mathrm{Pb}$ concentration compared to the unamended 
Table 3. Linear comelation coefficients between soil properties and the amount of biochar amended for a shooting range soil.

\begin{tabular}{|c|c|c|c|c|}
\hline \multirow{2}{*}{ Parameter } & \multicolumn{4}{|c|}{ Correlation coefficient } \\
\hline & $\mathrm{OM}^{\dagger}$ & TCLP-Pb & TCLP-Cu & $\mathrm{pH}$ \\
\hline Aggregate stability & $0.97^{* * *}$ & $-0.96^{* * *}$ & $0.81^{* *}$ & $0.92^{* * *}$ \\
\hline $\mathrm{CFU}$ bacteria & $0.94^{* * *}$ & $-0.96^{* * *}$ & $0.81^{* *}$ & $0.95^{* * *}$ \\
\hline CFU fungi & $0.97^{* * *}$ & $-0.97^{* * *}$ & $0.79^{* *}$ & $0.92^{* * *}$ \\
\hline Alkaline phosphatase & $0.99^{* * *}$ & $-0.84^{* *}$ & $0.82^{* *}$ & $0.77^{* *}$ \\
\hline Acid phosphatase & $0.94^{* * *}$ & $-0.81^{* *}$ & $0.90^{* * *}$ & $0.78^{* *}$ \\
\hline Urease & $0.97^{* * *}$ & $-0.89^{* * *}$ & $0.82^{* *}$ & $0.86^{* *}$ \\
\hline$\beta$-glucosidase & $0.99^{* * *}$ & $-0.88^{* * *}$ & $0.83^{* *}$ & $0.81^{* *}$ \\
\hline Dehydrogenase & $0.97^{* * *}$ & $-0.77^{* *}$ & $0.82^{* *}$ & $0.67^{*}$ \\
\hline
\end{tabular}

${ }^{\dagger}$ Organic matter.

p $<0.05$.

${ }^{* *}<0.01$.

${ }^{* * *} \mathrm{p}<0.001$
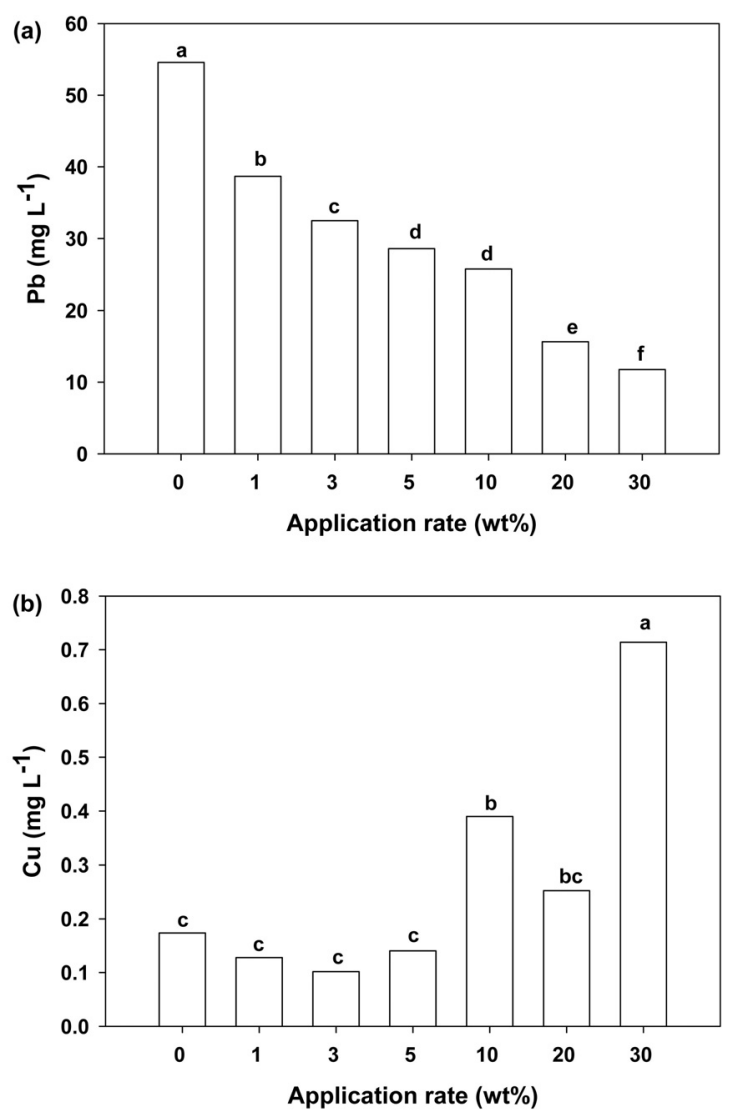

Fig. 1. (a) TCLP-Pb and (b) TCLP-Cu in shooting range soil amended with different application rates of biochar. Bars with same letters are not significantly different.

control (Fig. 1a). The $\mathrm{Pb}$ concentrations reduced gradually from $54.57 \mathrm{mg} \mathrm{L}^{-1}$ (unamended control) to a minimum of $11.75 \mathrm{mg} \mathrm{L}^{-1}$ (30\% BC application). Unlike $\mathrm{Pb}, \mathrm{Cu}$ showed a different trend. Amended shooting range soil with $\mathrm{BC}$ caused a pronounced increase in the TCLP-Cu concentration compared to the unamended control (Fig. 1b). The mean $\mathrm{Cu}$ concentration increased from $0.17 \mathrm{mg} \mathrm{L}^{-1}$ (unamended control) to $0.71 \mathrm{mg} \mathrm{L}^{-1}$ (30\% BC application). To investigate the effect of $\mathrm{BC}$ application on $\mathrm{Cu}$ mobilization, water extracted $\mathrm{Cu}$ (water- $\mathrm{Cu}$ ) and DOC were determined. The results indicated a significant increase of DOC by increasing the rate of $\mathrm{BC}$ applications. For soils amended with 1-30\% BC, the concentrations of DOC ranged from 1.44-12.39 folds greater than the unamended control. The mobilization of $\mathrm{Cu}$ was positively correlated with DOC $(\mathrm{r}=0.89, \mathrm{p}<0.001)$.

To investigate the distribution of $\mathrm{Pb}$ among different soil pools, sequential extraction analysis was done using 0 , 1, 10, 20 and 30\% BC amendments. The most abundant fraction of $\mathrm{Pb}$ in the unamended sample was the $\mathrm{Fe}-\mathrm{Mn}$ oxide fraction at $1,554 \mathrm{mg} \mathrm{kg}^{-1}$ (30.98\%) followed by residual 1,268 $\mathrm{mg} \mathrm{kg}^{-1}(25.27 \%)$ and $\mathrm{CO}_{3}$-bound 977.69 $\mathrm{mg} \mathrm{kg}^{-1}$ (19.49\%) fractions (Fig. 3). Application of BC induced a shift (14.49\%) of the exchangeable form of $\mathrm{Pb}$ (726.74 $\mathrm{mg} \mathrm{kg}^{-1}$ ) towards less available forms; however, the reduction of exchangeable form of $\mathrm{Pb}$ was dependent on the rate of $\mathrm{BC}$ application. At $30 \% \mathrm{BC}$ application, the exchangeable form of $\mathrm{Pb}$ was significantly transformed the organic bound and residual fractions at 459.54 and $1,318 \mathrm{mg} \mathrm{kg}^{-1}$, respectively (11.39 and 33.63\%).

Soil enzyme activities and microbial populations positively correlated with $\mathrm{BC}$ applications (Table 3). A negative correlation among soil enzyme activities, microbial populations, and TCLP-Pb indicated that soil biological properties improved when $\mathrm{Pb}$ availability was reduced pursuant to the transformation of $\mathrm{Pb}$ into less available 


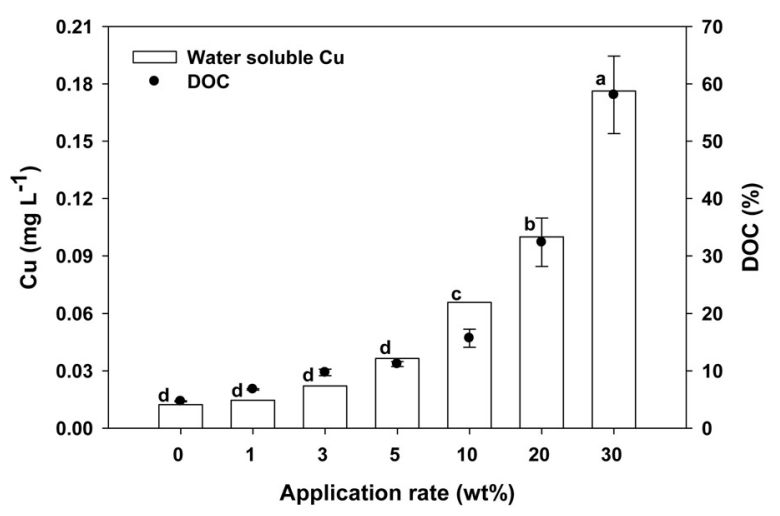

Fig. 2. Water soluble $\mathrm{Cu}$ and dissolved organic carbon (DOC) in shooting range soils amended with different application rates of biochar. Bars with same letters are not significantly different. Error bars on circles are standard deviations of four replicates.

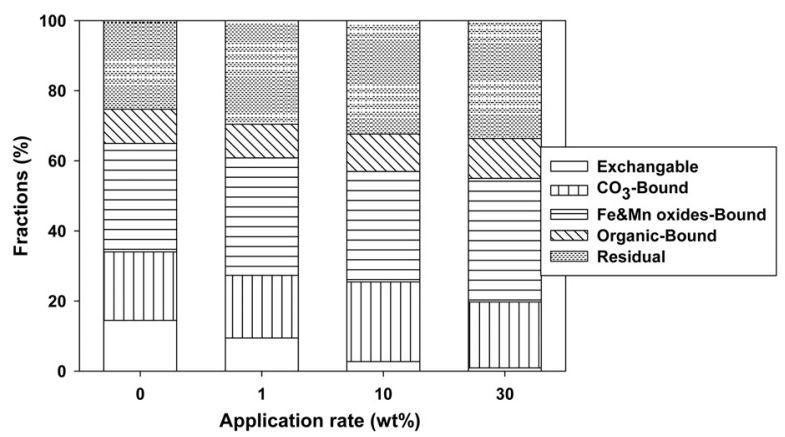

Fig. 3. Fractions ratio of $\mathbf{P b}$ in shooting range soils amended with different application rates of biochar.

forms. A positive correlation was observed between microbial populations and soil $\mathrm{pH}(\mathrm{p}<0.001), \mathrm{OM}(\mathrm{p}<0.001)$, and TCLP-Cu $(\mathrm{p}<0.01)$ indicating that soil biological properties have been enhanced when $\mathrm{Cu}$ availability was increased as a result of $\mathrm{Cu}$ mobilization in the shooting range soil amended with $\mathrm{BC}$ (Table 3).

\section{Chemical properties Table 2 shows selected chemical} properties of the $\mathrm{BC}$ amended shooting range soil after $30 \mathrm{~d}$ of incubation period. Soil $\mathrm{pH}$ was increased from 6.10 in unamended soil to a maximum of 8.22 in soil amended with $30 \%$ BC. Similarly, the EC increased up to $1.59 \mathrm{dS} \mathrm{m}^{-1}$ in soil amended with $30 \% \mathrm{BC}$ as compared to the unamended soil $\left(0.03 \mathrm{dS} \mathrm{m}^{-1}\right)$. The application of $30 \% \mathrm{BC}$ also increased soil $\mathrm{OM}, \mathrm{TC}$, and $\mathrm{TN}$, compared to unamended soil (all $\mathrm{p}<0.05$ ). The means of available $\mathrm{N}$ and $\mathrm{P}$ increased between 31.09-180.20 and 8.42-60.35 $\mathrm{mg} \mathrm{kg}{ }^{-1}$, respectively, depending on various application rates of $\mathrm{BC}$.
Biological properties Application of $\mathrm{BC}$ enhanced soil biological properties in terms of enzyme activities (Fig. 4) and microbial populations (Fig. 5). Results showed that the acid phosphatase was predominant in the applications of 0,1 and $3 \% \mathrm{BC}$. On the other hand, the alkaline phosphatase was predominant in the applications of 5, 10, 20 and $30 \%$ BC. The activities of alkaline phosphatase at rates of 5-30\% $\mathrm{BC}$ were 1.5-4.3 folds greater than that of acid phosphatase.

Applications of 30\% BC soil had the highest enzyme activity and microbial population, which were 7.06-fold (acid phosphatase), 54.52-fold (alkaline phosphatase), 7.81-fold (ß-glucosidase), 13.17-fold (urease), and 764.15 -fold (dehydrogenase) greater than the unamended soil $(p<0.05)$ (Table 3). The results indicated that bacterial population can be greatly enhanced by $\mathrm{BC}$ addition as compared to the fungal one. Similarly, the application of $30 \%$ BC had 40.44-fold and 10.55-fold of the colony forming units (CFUs) of bacteria and fungi, respectively, was greater than the unamended control $(\mathrm{p}<0.05)$ (Fig. 6).

\section{Discussion}

Aggregate stability Soil aggregate stability is a relevant indicator of soil erodibility and physical properties of the soil (Table 1). The initial shooting range soil indicated a low aggregate stability $(8.76 \%)$, mainly due to its low content of fine clay and silt fractions, and OM (1.40\%) (Milne and Haynes, 2004; Tisdall and Oades, 1982). However, an increase in the application rate of $\mathrm{BC}$ indicated the increasing potential to increase soil aggregate stability (Table 2). Incorporation of $\mathrm{OM}$ from $\mathrm{BC}$ could be the possible reason of gradual increase in soil aggregate stability (Gregory and Vickers, 2003; Lal, 1998). An increase in OM may increase soil stability (Brodowski et al., 2006; Metzger et al., 1987). Organic matter compounds derived from $\mathrm{BC}$ might act as an agent for binding mineral particles together into microaggregates, thereby enhancing soil aggregate stability.

Chemical properties Soil chemical parameters such as $\mathrm{pH}, \mathrm{OM}$, and nutrient availability have been used as indicators of soil quality (Chan et al., 2007; Doran and Parkin, 1996; Glaser et al., 2002; Gil-Sotres et al., 2005). With addition of $\mathrm{BC}$, increases in soil $\mathrm{OM}$, soil $\mathrm{pH}, \mathrm{EC}$, and available $\mathrm{N}$ and $\mathrm{P}$ were observed (Table 2). The $\mathrm{BC}$ had a higher level of TN (2.73\%) while the mineral $\mathrm{N}$ was 

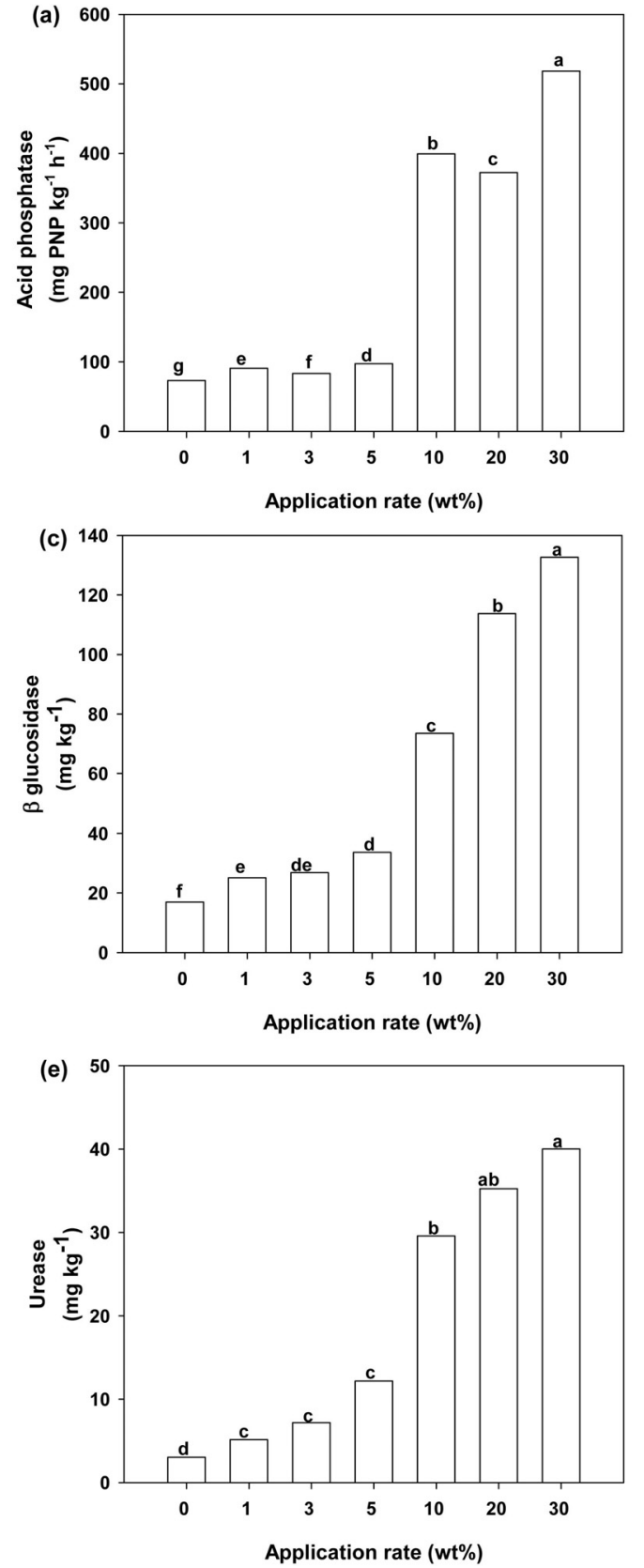
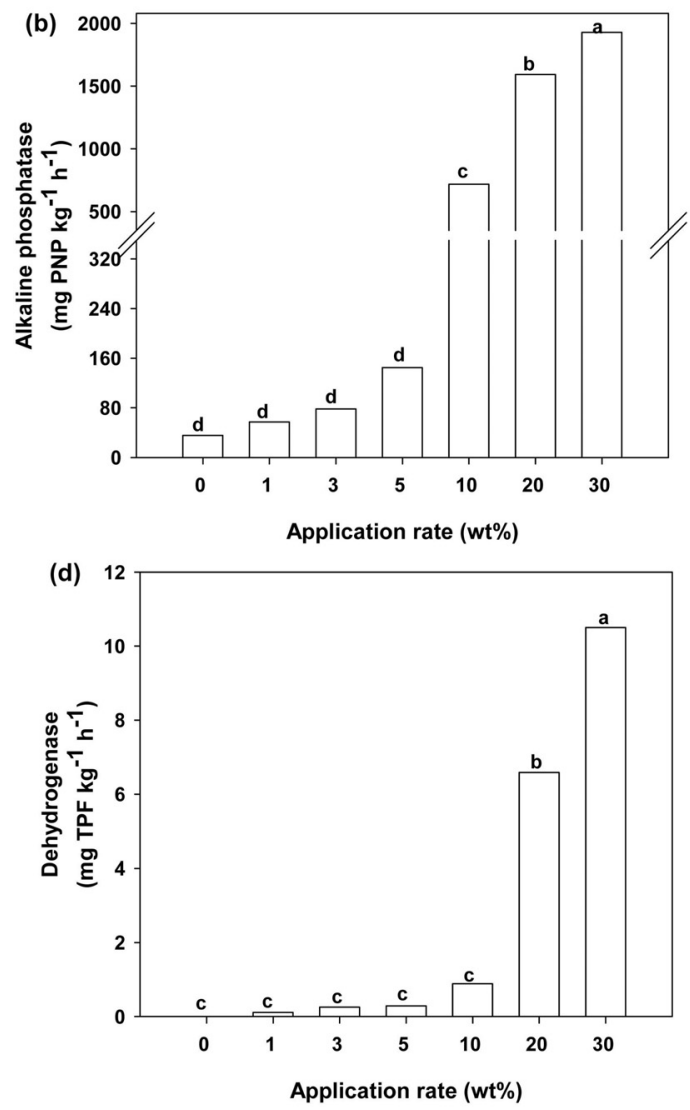

Fig. 4. Enzyme activities in shooting range soils amended with different application rates of biochar. Bars with same letters are not significantly different at $\mathbf{0 . 0 5}$ significant level.

low at $0.3 \%$. Because of the $\mathrm{BC}$ priming effect, the mineralization rate and organic $\mathrm{N}$ in the soil may be increased (Xu et al., 2006). Significantly, high values of soil $\mathrm{pH}$ were found under different rates of $\mathrm{BC}$ compared to the unamended control. The addition of $30 \% \mathrm{BC}$ increased soil $\mathrm{pH}$ by 2.1 units. The rise in soil $\mathrm{pH}$ could be explained by the ammonification process, as indicated by the increase of soil ammonium concentration by increasing the rate of BC application (data not shown). Specifically, ammonification produces hydroxyl ions that can lead to increases in soil pH (Xu et al., 2006). Another possible explanation is that $\mathrm{BC}$ can have a liming effect on the soil pH (vanZwieten et al., 2009); therefore, the application of $\mathrm{BC}$ to shooting range soils increases the soil $\mathrm{pH}$. Moreover, the addition of $\mathrm{BC}$ raised the soil salinity or EC. The soil salinity increased up to $1.60 \mathrm{dS} \mathrm{m}^{-1}$ with increasing application rate of $\mathrm{BC}$. The significant increase in soil salinity was mainly due to the release of the ions during the $\mathrm{OM}$ decomposition (Moreno et al., 1999; Usman et al., 2004). The addition of $\mathrm{BC}$ to shooting range soil caused a significant increase in available nutrients because application of $\mathrm{BC}$ provides additional sources of nutrients through the 

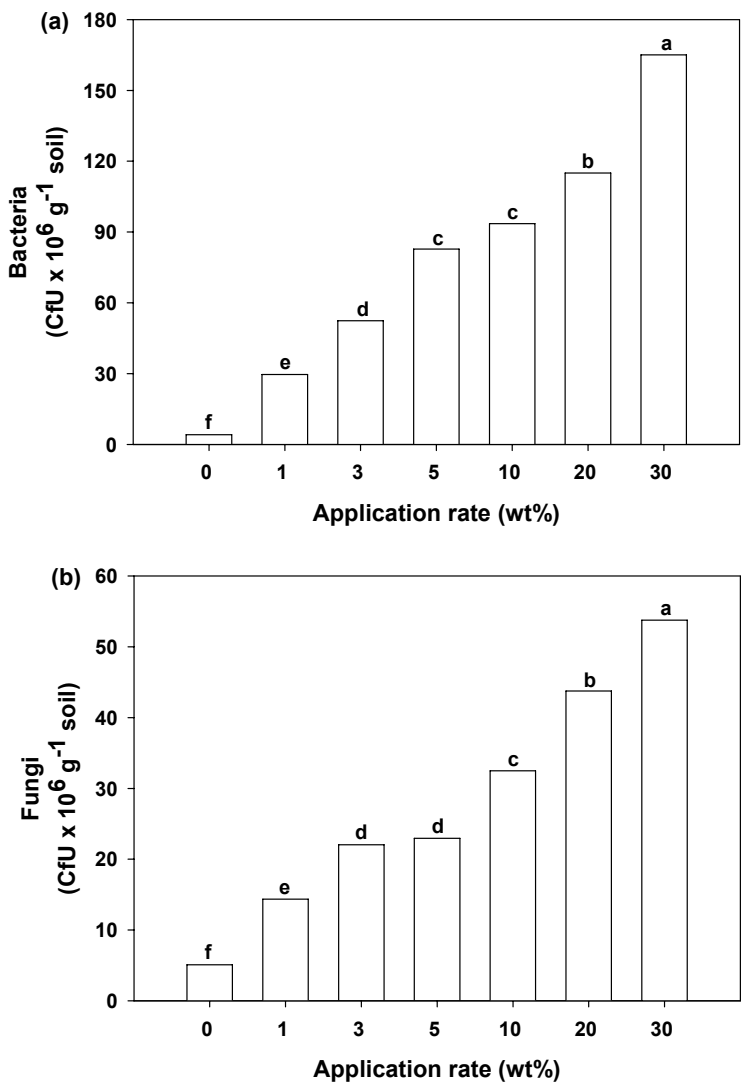

Fig. 5. Populations of (a) bacteria and (b) fungi in shooting range soil amended with different application rates of biochar. Bars with same letters are not significantly different at 0.05 significant level.

decomposition of OM (Moreno et al., 1999). Previous studies have identified that BC applied to soils improved the availability of P to plants (Glaser et al., 2002; Lehman et al., 2003). Pyrolysis of organic biomass from 400 to $700^{\circ} \mathrm{C}$ results in high concentrations of $\mathrm{C}$ and $\mathrm{N}$ (Antal and Gronli, 2003). As evidences, our findings show that TC and TN were significantly elevated from 0.65 and $0.03 \%$ (unamended control) to 13.43 and $0.59 \%$ (30\% $\mathrm{BC}$ application). Our findings suggest that the potential for increasing soil $\mathrm{OC}$, soil $\mathrm{pH}, \mathrm{TN}$, and available $\mathrm{N}$ and $\mathrm{P}$ due to increasing $\mathrm{BC}$ application rate.

Heavy metals availability Addition of organic amendments to contaminated soils has been widely used to reduce toxicity and availability of heavy metals (Gadepalle et al., 2007). In this study, addition of BC to shooting range soil caused a significant decrease in TCLP-Pb up to $78.5 \%$ with $30 \% \mathrm{BC}$ application (Fig. 1). The exchangeable fraction of $\mathrm{Pb}$ also reduced up to $93.68 \%$ with $30 \% \mathrm{BC}$ application. The changes of $\mathrm{Pb}$ fractions in the shooting range soils after $\mathrm{BC}$ application indicated that the readily available form of $\mathrm{Pb}$ in $\mathrm{BC}$ amended soil was converted into less available form of organic bound fraction (16.67 $\%$ ) and unavailable form of residual fraction (33.05\%) (Fig. 2). Soil pH plays an important role in affecting the solubility and availability of heavy metals in soil (Ok et al., 2008; Ok et al., 2010). A negative correlation was observed between TCLP-Pb and soil $\mathrm{pH}(\mathrm{p}<0.001)$ (Table 3 ), suggesting that $\mathrm{pH}$ controls the availability of $\mathrm{Pb}$ in the $\mathrm{BC}$-amended shooting range soil. These findings agree with studies of Cao et al. (2008) and Hashimoto et al. (2009a). They reported that the use of alkaline amendments caused a significant increase in soil $\mathrm{pH}$ and a reduction of the TCLP-extracted $\mathrm{Pb}$. These are mainly resulted from the high content of OM in BC. Several studies indicated that $\mathrm{OM}$ reduces metal availability and mobility by the metal adsorption on the surface of OM, as well as the formation of stable insoluble organomineral complexes (Shuman, 1999; Walker et al., 2004). For an increase in residual fraction, there are two different possible mechanisms for the transformation of $\mathrm{Pb}$. One is the formation of $\mathrm{Pb}(\mathrm{OH})_{2}$ which is more stable at high $\mathrm{pH} 8$ (Lindsay, 1979). Hashimoto et al. (2009b) suggested that poultry litter ash increased soil $\mathrm{pH}$ and stabilized $\mathrm{Pb}$ by precipitation and coprecipitation of hydroxides. The other possibility is the formation of stable $\mathrm{Pb}$-pyromorphite by the reaction between available $\mathrm{Pb}$ and $\mathrm{P}$ in the $\mathrm{BC}$-amended shooting range soil (Hashimoto et al., 2009b). Cao et al. (2009) indicated that high content of $\mathrm{P}$ in the $\mathrm{BC}$ was mainly responsible for $\mathrm{Pb}$ stabilization via formation of stable phosphate minerals.

By contrast, $\mathrm{BC}$ addition enhanced the mobilization of $\mathrm{Cu}$ in the shooting range soil. The $30 \% \mathrm{BC}$ application increased the TCLP-Cu 4.11-folds greater than the unamended control (Fig. 2). Similarly, BC increased the watersoluble $\mathrm{Cu} 14.33$-folds greater than the unamended control (Fig. 4). It is evidence that DOC complexes the cationic trace metals and enhance their mobility (Spuller et al., 2007). Consequently, the mobilization of OM as indicated by the elevated DOC concentrations favor the leaching of mobile $\mathrm{Cu}-\mathrm{DOC}$ complexes. The mobilization of $\mathrm{Cu}$ is highly correlated with DOC $(p<0.001)$. Similarly, positive correlation between $\mathrm{Cu}$ and DOC concentrations was found in soil leachate of a highly contaminated soil (Kalbitz and Wennrich, 1998). However, the mobilization of $\mathrm{Cu}$ in the $\mathrm{BC}$-amended shooting range soil was too low to cause any detrimental effect. Furthermore, availability of this amount of $\mathrm{Cu}$ to plants might be beneficial as an 
essential nutrient.

Biological properties Soil microbial populations and enzyme activities are sensitive to soil heavy metal pollution. Typically, soil microbial populations have assumed to play a role in the soil, related to synthesis and decomposition of soil $\mathrm{OM}$ and the cycling of nutrients (Wardle and Giller, 1996). Therefore, microbial populations and enzyme activities are very important for the maintenance of soil fertility and they can serve as indicators for soil biological quality. Lee et al. (2002) indicated that most enzyme activities were lower at the shooting range soil due to high $\mathrm{Pb}$ concentration. Our results indicated that the addition of $\mathrm{BC}$ to shooting range soil enhanced the activity of various soil enzymes and the growth of microbial populations (bacteria and fungi) (Fig. 4, 5). Acid phosphatase was predominant in the 0,1 and $3 \% \mathrm{BC}$ applications with $\mathrm{pH}$ values of 6.10-7.20 compared to alkaline phosphatase activity. On the other hand, alkaline phosphatase was predominant at $5-30 \% \mathrm{BC}$ applications along with $\mathrm{pH}$ values of 7.68-8.22. These findings are supported by a previous work of Acosta-Martinez and Tabatabai (2004) who reported that acid phosphatase is predominant in acid soils and alkaline phosphatase is predominant in alkaline soils. It is well know that the low soil $\mathrm{pH}$ decreased both microbial activities and $\mathrm{OM}$ mineralization (Xu et al., 2006). Our results showed that the activity of acid and alkaline phosphatase, urease, $\beta$-glucosidase, and dehydrogenase have positive correlations with soil $\mathrm{pH}(\mathrm{p}<0.01)$. The activities of invested enzymes were also positively correlated $(\mathrm{p}<0.001)$ with soil OM. A negative correlation was observed between enzyme activities and TCLP-Pb. Specifically, urease and $\beta$-glucosidase enzymes are sensitive to $\mathrm{Pb}(\mathrm{p}<0.001)$ indicating that soil microbial populations and enzyme activities were enhanced due to reducing $\mathrm{Pb}$ availability by immobilization. Application of $\mathrm{BC}$ would help mitigate soil acidity and $\mathrm{Pb}$ toxicity to soil microorganisms, resulting in improvements in soil biological quality. In addition, both microbial populations and enzyme activity could be potential biological indicators of soil quality changes.

\section{Conclusion}

The excessive accumulations of $\mathrm{Pb}$ in shooting range soils pose potential environmental problems. Our results clearly indicated that a potential existed for $\mathrm{BC}$ to improve soil quality in terms of soil physicochemical and biological properties as well as to stabilize $\mathrm{Pb}$ in a military shooting range soil. Application of $\mathrm{BC}$ increased aggregate stability, $\mathrm{OM}$, available $\mathrm{N}$ and $\mathrm{P}$, microbial populations and enzyme activities of shooting range soil. The $\mathrm{BC}$ significantly reduced exchangeable form of $\mathrm{Pb}$ to relatively stable forms, including organically bound fraction due to the increase in soil $\mathrm{OM}$, and residual fraction. Our study suggests that at high $\mathrm{pH}$ induced by $\mathrm{BC}, \mathrm{Pb}$ would eventually form relatively insoluble minerals. In addition, high contents of $\mathrm{P}$ in the amended shooting range soil might be responsible for the formation of stable $\mathrm{Pb}$-phosphate minerals and therefore, decreasing the mobility of $\mathrm{Pb}$. Our results suggest that the shooting range soils severely contaminated with heavy metals can be restored using BC application. In addition, the economical evaluation for using biochar should be investigated in the future.

\section{Acknowledgement}

This study was supported by a National Research Foundation of Korea Grant funded by the Korean Government (Project number: 2009-0071439).

\section{References}

Aboulroos, S.A., M.I.D. Helal, and M.M. Kamel. 2006. Remediation of $\mathrm{Pb}$ and $\mathrm{Cd}$ polluted soils using in situ immobilization and phytoextraction techniques. Soil Sediment Contam. 15:199-215.

Acosta-Martines, V. and M.A. Tabatabai. 2004. Enzyme activities in a limed agricultural soil. Biol. Fertil. Soils 31:85-91.

Antal, M.J. Jr. and M. Gronli. 2003. The art, science, and technology of charcoal production. Ind. Eng. Chem. Res. 42:1619-1640.

Belyaeva, O.N., R.J. Haynes, and O.A. Birukova. 2005. Barely yield and soil microbial and enzyme activities as affected by contamination of two soils with lead, zinc, or copper. Biol. Fertil. Soils. 41:85-94.

Brodowski, S., B. John, H. Flessa, and W. Amelung. 2006. Aggregate-occluded black carbon in soil. Eur. J. Soil Sci. 157:539-546.

Cao, X., D. Dermatas, X. Xu, and G. Shen. 2008. Immobilization of lead in shooting range soils by means of cement, quicklime, and phosphate amendments. Environ. Sci. Pollut. Res. 15:120-127.

Cao, X., L. Ma, B. Gao, and W. Harris. 2009. Dairy-manure derived biochar effectively sorbs lead and atrazine. Environ. Sci. Technol. 43:3285-3291. 
Chan, K.Y., L. van Zwieten, I. Meszaros, A. Downie, and S. Joseph. 2007. Agronomic values of green waste biochar as a soil amendment. Aust. J. Soil Res. 45:629-634.

Chen, M. and S.H. Daroub. 2002. Characterization of lead in soils of a rifle/pistol shooting range in central Florida, USA. Soil Sediment Contam. 11:1-17.

Chirenje, T., L.Q. Ma, M.Chen, and E.J. Zillioux. 2003. Comparison between background concentrations of arsenic in urban and non-urban areas of Florida, Adv. Environ. Res. 8:137-146.

Craig, J.R. 1999. Surface water transport of lead at a shooting range. Bull. Environ. Contam. Toxicol. 63:312-319.

Dermatas, D., M. Chrysochoou, D.G. Grubb, and X. Xu. 2008. Phosphate treatment of firing range soils: Lead fixation or phosphorus release? J. Environ. Qual. 56:37-47.

Dermatas, D., X. Cao, V. Tsaneva, G. Shen, and D.G. Grubb. 2006. Fate and behavior of metal(loid) contaminants in an organic matter-rich shooting range soil: Implications for remediation. Water Air Soil Pollut. 6:143-155.

Doane, T.A. and W.R. Horwath. 2003. Spectrophotometric determination of nitrate with a single reagent. Anal. Lett. 36:2716-2722.

Doran, J.W. and T.B. Parkin. 1996. Quantitative indicators of soil quality: a minimum data set. p. 25-37. In J.W. Doran, and A.J. Jones (eds.) Methods for Assessing Soil Quality, 49, Special Publication, Soil Sci. Soc. Am., Madison, WI, USA.

Free, H.F., C.R. McGill, J.S. Rowarth, and M.G. Hedley. 2010. The effect of biochar on maize (Zea mays) germination. New Zealand J. Agric. Res. 53:1-4.

Gadepalle, V.P., S.K. Ouki, R.V. Herwijnen, and T. Hutchings. 2007. Immobilization of heavy metals in soil using natural and waste materials for vegetation establishment on contaminated sites. Soil Sediment Contam. 16:233-251.

Gee, G.W. and D. Or. 2002. Particle size analysis. p. 278-282 In A.W. Dick (ed.) Methods of Soil Analysis, Part 4, Physical Methods. Soil Sci. Soc. Am., Madison, WI, USA.

Gil-Sotres, F., C. Trasar-Cepeda, M.C. Leiros, and S. Seoane. 2005. Different approaches to evaluating soil quality using biochemical properties. Soil Biol. Biochem. 37:877-887.

Glaser, B., J. Lehmann, and W. Zech. 2002. Ameliorating physical and chemical properties of highly weathered soils in the tropics with charcoal - a review. Biol. Fertil. Soils 35:219-230.

Gregory, A.S. and A.W. Vickers. 2003. Effects of amendments on soil structural development in a clay soil-forming materials used as a cap for landfill restoration. Soil Use Manage. 19:273-276.

Grubb, D.G., D.H. Moon, T. Reilly, M. Vhtysochoou, and D. Dermatas. 2009. Stabilization/solidification $(\mathrm{S} / \mathrm{S})$ of $\mathrm{Pb}$ and W contaminated soils using type I/II Portland cement, silica fume cement and cement kiln dust. Glob Nest J. 11: 267-282.

Hamer, U., B. Marschner, S. Brodowski, and W. Amelung. 2004. Interactive priming of black carbon and glucose mineralization. Org. Geochem. 35:823-830.

Hashimoto, Y., T. Taki, and T. Sato. 2009a. Sorption of dissolved lead from shooting range soils using hydroxyapatite amendments synthesized from industrial byproducts as affected by varying $\mathrm{pH}$ conditions. J. Environ. Manage. 90:1782-1789.

Hashimoto, Y., T. Tahi, and T. Sato. 2009b. Extractability and leachability of $\mathrm{Pb}$ in a shooting range soil amended with poultry litter ash: Investigation for immobilization potentials. J. Environ. Sci. Health A 44:583-590.

Hashimoto, Y., M. Takaoka, and S. Shiota. 2010. Enhanced transformation of lead speciation in rhizosphere soils using phosphorus amendments and phytostabilization: An X-ray absorption fine structure spectroscopy investigation. J. Environ. Qual. Doi: 10.2134/jeq2010.0057.

Kalbitz, K. and R. Wennrich. 1998. Mobilization of heavy metals and arsenic in polluted wetland soils and its dependence on dissolved organic matter. Sci. Total Environ. 209:27-39.

Kuo, S. 1996. Phosphorus. p. 869-919. In D.L. Sparks, A.L. Page, P.A. Helmke, R.H. Loeppert, P.N. Soltanpour, M.A. Tabatabai, C.T. Johnston, and M.E. Sumner (eds.) Methods of Soil Analysis, Part 3, Chemical Methods, Soil Sci. Soc. Am., Madison, USA.

Lal, R. 1998. Soil degradation. p. 237-253. In J. Sehgal, W.E. Blum, K.S. Gajbhiye (eds.) Red \& Lateritic soils, Oxford and IBH Publishing Co., New Delhi, India.

Lee, I.S., O.K. Kim, Y.Y. Chang, B. Bae, H.H. Kim, and K.H. Baek. 2002. Heavy metal concentrations and enzyme activities in soil from a contaminated Korean shooting range. J. Biosci. Bioeng. 94:406-411.

Lehman, J., J.P. da Silva Jr., C. Steiner, T. Nehls, W. Zech, and B. Glaser. 2003. Nutrient availability and leaching in an archaeological Anthrosol and a Ferrasol of the central Amazon basin: Fertilizer, manure and charcoal amendments. Plant Soil 249:343-357.

Lehmann, J. and S. Joseph. 2009. Introduction. p. 1-12. In J. Lehmann, and S. Joseph (eds.) Biochar for environmental management. Science and technology, Earthscan, London, UK.

Li, H., W.Y. Shi, H.B. Shao, and M.A. Shao. 2009. The remediation of the lead-polluted soil by natural zeolite. J. Hazard. Mater. 169:1106-1111.

Lindsay, W.L. 1979. Chemical Equilibria in Soils. John Wiley \& Sons Inc., NJ, USA.

Major, J. 2010. A guide to conducting biochar trials. Int. Biochar Initiative. http://www.biochar-international.org

Mellor, A. and C. McCartney. 1994. The effects of lead shot deposition on soils and crops at a clay pigeon shooting site in northern England. Soil Use Manage. 10:124-129.

Metzger, L., O. Levanon, and V. Mingelgrin. 1987. The effect of sewage sludge on soil structural stability: microbiological aspects. Soil Sci. Soc. Am. J. 51:346-351.

Milne, R.M. and R.G. Haynes. 2004. Soil organic matter, microbial properties, and aggregate stability under annual perennial pastures. Biol. Fertil. Soils 39:172-178.

MOE. 2010. Soil Environment Conversation Act. Ministry of Environment, Korea.

Moon, D.H., K.H. Cheong, T.S. Kim, J. Khim, S.B. Choi, Y.S. Ok, and O.R. Moon. 2010. Stabilization of $\mathrm{Pb}$ contaminated army firing range soil using calcinated waste oyster shells. J. Korean Soc. Environ. Eng. 32:1353-1358. (In Korean) 
Moreno, J.L., T. Hernandez, and C. Garcia. 1999. Effects of a cadmium-contaminated sewage sludge compost on dynamics of organic matter and microbial activity in an arid soil. Biol. Fertil. Soils 28:230-237.

Mulligan, C.N., R.N. Yong, and B.F. Gibbs. 2001. Remediation technologies for metal-contaminated soils and groundwater: an evaluation. Eng. Geol. 60:193-207.

Nelson, D.W. and L.E. Sommers. 1996. Total carbon, organic carbon, and organic matter. p. 961-1010. In A.L. Page et al. (ed.) Methods of Soil Analysis, Part 2, 2nd ed., Am. Soc. Agron., Madison, WI, USA.

NIAST. 2000. Method of soil and plant analysis. National Institute of Agricultural Science and Technology, Suwon, Korea. (In Korean)

Novak, J.M., W.J. Busscher, D.L. Larid, M. Ahmedna, D.W. Watts, and M.A.S. Niandou. 2009. Impact of biochar amendment on fertility of a Southeastern Coastal Plain soil. Soil Sci. 174:105:112.

Ok, Y.S., S.E. Oh, M. Ahmad, S. Hyun, K.R. Kim, D.H. Moon, S.S. Lee, K.J. Lim, W.T. Jeon, and J.E. Yang. 2010. Effects of natural and calcined oyster shells on $\mathrm{Cd}$ and $\mathrm{Pb}$ immobilization in contaminated soils. Environ. Earth Sci. 61:1301-1308.

Ok, Y.S., S.X. Chang, and Y. Feng. 2008. The role of atmosphereic $\mathrm{N}$ deposition in soil acidification in forest ecosystems. p. 314-369. In M.L. Sanchez (ed.) Ecological research progress. Nova Science Publishers, New York, USA.

Selmer-Olsen, A.R. 1971. Determination of ammonium in soil extract by an automated indophenols method. Analyst. 96: 565-568.

Shi, C. and R. Spence. 2004. Designing of cement-based formula for solidification/stabilization of hazardous, radioactive, and mixed wastes. Critical Review. Environ. Sci. Technol. 34:391-417.

Shuman, L.M. 1999. Organic waste amendments effect on zinc fractions of two soils. J. Environ. Qual. 28:1442-1447.

Singh, R.P. and M. Agrawal. 2007. Effects of sewage sludge amendment on heavy metal accumulation and consequent responses of Beta vulgaris plants. Chemosphere 67:22292240 .

Singh, T.S. and K.K. Pant. 2006. Solidification/stabilization of arsenic containing solid wastes using Portland cement, fly ash and polymeric materials. J. Hazard. Mater. 131:29-36.

Spuller, C., H. Weigand, and C. Marb. 2007. Trace metal stabilization in a shooting range soil: Mobility and phytotoxicity. J. Hazard Mater. 141:378-387.

Tabatabai, M.A. 1994. Soil enzymes. p. 775-883. In R.W. Weaver (ed.) Methods of Soil Analysis, Part 2, Microbiological and Biochemical Properties, Madison, WI, USA.

Taok, M., N. Cochet, A. Pauss, and O. Schoefs. 2007. Monitoring of microbial activity in soil using biological oxygen demand measurement and indirect impedancemetry. Eur. J. Soil Biol. 43:335-340.
Tessier, A., P.G.C. Campbell, and M. Bisson. 1979. Sequential extraction procedure for the speciation of particulate trace metals. Anal. Chem. 51:844-851.

Tisdall, J.M. and J.M. Oades. 1982. Organic matter and water stable aggregates in soils. J. Soil Sci. 33: 141-163.

Uchimiya, M., I.M. Lima, K.T. Klasson, S.C. Chang, L.W. Wartelle, and J.E. Rodgers. 2010. Immobilization of heavy metal ions (CuII, CdII, NiII, and PbII) by broiler litter-derived biochars in water and soil. J. Agric. Food Chem. 58:55385544.

USEPA. 1992. Method 1311 Toxicity characteristic leaching procedure. The US Environmental Protection Agency, Washington, DC, USA.

USEPA. 1996. Soil Screening Guidance: User's Guidance EPA 540/R-96/018, Office of Solid and Emergency Response. The US Environmental Protection Agency, Washington, DC, USA.

Usman, A.R.A., Y. Kuzyakov, and K. Stah. 2004. Dynamics of organic $\mathrm{C}$ mineralization and the mobile fraction of heavy metals in a calcareous soil incubated with organic wastes. Water Air Soil Pollut. 158:401-418.

vanZwieten, L., B. Singh, S. Joseph, S. Kimber, A. Cowie, and K.Y. Chan. 2009. Biochar and Emissions of Non- $\mathrm{CO}_{2}$ Greenhouse Gases from Soil. In J. Lehmann, and S. Joseph (eds.) Biochar for environmental management. Science and technology, Earthscan, London, UK.

Verheijen, F., S. Jeffery, A.C. Bastos, M. van der Velde, and I. Diafas. 2010. Biochar application to soils: A critical scientific review of effects on soil properties, processes and functions. Scientific and Technical Reports. European Commission, Joint Research Centre, Institute for Environment and Sustainability, Ispra, Italy.

Walker, D.J., R. Clemente, and M.P. Bernal. 2004. Contrasting effects of manure and compost on soil $\mathrm{pH}$, heavy metal availability and growth of Chenopodium album L. in a soil contaminated by pyritic mine waste. Chemosphere 57:215-224.

Wardle, D.A. and K.E. Giller. 1996. The quest for a contemporary ecological dimension to soil biology. Soil Biol. Biochem. 28:1549-1554.

$\mathrm{Xu}$, J.M., C. Tang, and Z.L. Chen. 2006. The role of plant residues in $\mathrm{pH}$ change of acid soils differing in initial $\mathrm{pH}$. Soil Biol. Biochem. 38:709-719.

Yeboah, E., P. Ofori, G.W. Quansah, E. Dugan, and S.P. Sohi. 2009. Improving soil productivity through biochar amendments to soils. African J. Environ. Sci. Technol. 3:34-41.

Yerokun, O.A., S. Chikuta, and D. Mambwe. 2007. An evaluation of spectroscopic and loss on ignition methods for estimating soil organic carbon in Zambian soils. Int. J. Agric. Res. 2: 965-970.

Yin, X., U.K. Saha, and L.Q. Ma. 2010. Effectiveness of best management practices in reducing $\mathrm{Pb}$-bullet weathering in a shooting range in Florida. J. Hazard. Mater. 179: 895-900. 